\title{
Design for Sensory Impaired, Elderly, and People with Disabilities in Saudi Arabia: Current Practices and Future Prospects
}

\author{
Tarik M. A. Al-Soliman \\ Professor \\ College of Arch. \& Planning, King Saud University, Kingdom of Saudi Arabia \\ Talsolman@ksu.edu.sa /tarikms@hotmail.com
}

(Received 8/3/2020; accepted for publication 12/4/2020.)

\begin{abstract}
With a population of $(33,413,660)$ in 2017 , Saudi Arabia has a relatively young society. People who are aged between $(0 \& 14)$ years account for $(25.16 \%)$, whereas those who are (65) years \& over account for $(3.3 \%)$. This percentage jumped to $(4.19 \%)$ in 2018 . Sensory impairment in addition to mobility problems are expected to affect the way in which this aging segment interacts with the surrounding environment. On the other hand, the working \& active segment aged between (15 \& 64) years accounted for $(71.5 \%)$. Such an age group is plagued by a crippling challenge manifested by car accidents casualties. The open \& built environments accommodating both groups are dealt with in a manner that is not responsive to the needs of the two groups positively. This paper elaborates on current practices \& discusses future prospects for the enhancement of open \& built environments accommodating people with special needs.
\end{abstract}

Keywords: Sensory Impairment, Elderly, Disabilities, Environmental Design.

\section{Introduction}

Saudi Arabia has a relatively young society. In 2017, approximately (25.16\%) of Saudi Arabia's population was aged between $(0 \& 14)$ years, about $(71.54 \%)$ were aged between (15 \& 64) years, and about $(3.3 \%)$ were aged more than 65 years [1]. By mid-2018, the ratios changed to (30.32\%), $(65.19 \%$, \& $4.19 \%)$ respectively.[2] These percentages describe age structure for Saudi citizens only, whereas the first figures include non-Saudi population which accounted for $(12,645,033)$ expatriates compared to $(20,768,627)$ Saudis.

Even with a percentage of 4.19 percent for citizens who are 65 years \& more, the percentage of elderly is still low compared to world percentage of 9.0 percent.[3] However, the number of Saudis who are 65 years \& over has risen from $(854,281)$ in 2017 to $(871,162)$ in 2018 , with an increase of (1.9\%) (Table, 1 \& 2)[4] [2]. With aging comes the symptoms of sensory impairment, both mild \& severe. Also, mobility problems could be expected for this age group due to increased dependence on auto vehicles for movement within geographically expanding cities. [5]

On the other hand, Saudi Arabia is facing a real challenge affecting its young population. Car accidents' casualties has led to more than $(9,031)$ deaths \& $(30,217)$ injuries in the year $(2018)$.

Both groups, old \& young, need special care when planning for \& designing open \& closed spaces. This paper discusses the current situation in dealing with these two groups, \& looks for future prospects. [6]

\section{SENSORY IMPAIRED (Vision)}

Aging is associated with many biological, psychological \& mental changes. Aging people experience gradual changes in vision, hearing, balance, coordination, \& memory.[7]. As people 
Table 1. Saudi Population (65 Years and over) by sex, Age Groups and Nationality (Saudi/Non-Saudi).

\begin{tabular}{|c|c|c|c|c|c|c|c|c|c|}
\hline \multirow[b]{2}{*}{$\begin{array}{c}\text { Age } \\
\text { Group }\end{array}$} & \multicolumn{3}{|c|}{ Total } & \multicolumn{3}{|c|}{ Non-Saudi } & \multicolumn{3}{|c|}{ Saudi } \\
\hline & Total & $\begin{array}{c}\text { Female } \\
\mathrm{s}\end{array}$ & Males & Total & Females & Males & Total & Females & Males \\
\hline $65-69$ & 414180 & 189172 & 225008 & 103821 & 29590 & 74231 & 310359 & 159582 & 150777 \\
\hline $70-74$ & 275876 & 131914 & 143962 & 53058 & 19101 & 33957 & 222818 & 112813 & 110005 \\
\hline $75-79$ & 164639 & 77634 & 87005 & 20560 & 4697 & 15863 & 144079 & 72937 & 71142 \\
\hline $80+$ & 196190 & 98176 & 98014 & 19165 & 6619 & 12546 & 177025 & 91557 & 85468 \\
\hline Total & 1050885 & 496896 & 553989 & 196604 & 60007 & 136597 & 854281 & 436889 & 417392 \\
\hline
\end{tabular}

Source : General Authority for Statistics (2017).

Table 2.Population \& Demography Population in Kingdom by Gender, Age Group and Nationality (Saudi/non-Saudi) Mid 2018 A.D..

\begin{tabular}{|c|c|c|c|c|c|c|c|c|c|}
\hline \multicolumn{3}{|c|}{ Total } & \multicolumn{3}{|c|}{ Non-Saudi } & \multicolumn{3}{|c|}{ Saudi } & \multirow[b]{2}{*}{$\begin{array}{c}\text { Age } \\
\text { Group }\end{array}$} \\
\hline Total & Female & Male & Total & Female & Male & Total & Female & Male & \\
\hline $2,788.931$ & $1,367,544$ & $1,421,387$ & 581,141 & 283,015 & 298.126 & $2,207,790$ & $1,084,529$ & $1,123,261$ & $0-4$ \\
\hline $2,895,637$ & 1,420685 & $1,474,952$ & 737,163 & 360,021 & 377,142 & $2,158,474$ & $1,060,664$ & $1,097,810$ & $5-9$ \\
\hline $2,536,312$ & $1,246,253$ & $1,290,059$ & 604,101 & 293,553 & 310,548 & $1,932,211$ & 952,700 & 979,511 & $10-14$ \\
\hline $2,312,755$ & $1,132,037$ & $1,180,718$ & 491,753 & 237,191 & 254,562 & $1,821,002$ & 894,846 & 926,156 & 1519 \\
\hline $2,576,498$ & $1,203,773$ & $1,372,725$ & 524,184 & 223,588 & 300,596 & $2,052,314$ & 980,185 & $1,072,129$ & $20-24$ \\
\hline $3,189,330$ & $1,428,320$ & $1,761,010$ & $1,218,061$ & 453,068 & 764,993 & $1,971,269$ & 975,252 & 996,017 & 2529 \\
\hline $3,230,441$ & $1,332,414$ & $1,898,027$ & $1,451,690$ & 450,453 & $1,001,237$ & $1,778,751$ & 881,961 & 896,790 & 3034 \\
\hline $3,605,004$ & $1,347,654$ & $2,257,350$ & $2,049,608$ & 579,037 & $1,470,571$ & $1,555,396$ & 768,617 & 786,779 & 3539 \\
\hline $3,223,846$ & $1,169,310$ & $2,054,536$ & $1,916,761$ & 528,066 & $1,388,695$ & $1,307,085$ & 641,244 & 665,841 & $40-44$ \\
\hline $2,393,995$ & 813,067 & $1,580,928$ & $1,304,906$ & 283,517 & $1,021,389$ & $1,089,089$ & 629,550 & 559,539 & $45-49$ \\
\hline $1,670,297$ & 528,518 & $1,141,779$ & 802,098 & 106,590 & 695,508 & 868,199 & 421,928 & 446,271 & $50-54$ \\
\hline $1,153,898$ & 389,390 & 764,508 & 486,102 & 69,675 & 416,427 & 667,796 & 319,715 & 348,081 & 5559 \\
\hline 760,864 & 285,780 & 475,084 & 272,775 & 49,848 & 222,927 & 488,089 & 235,932 & 252,157 & $60-64$ \\
\hline $1,075,852$ & 507,959 & 567,893 & 204,690 & 62,350 & 142,340 & 871,162 & 445,609 & 425,553 & $65-$ \\
\hline $33,413,660$ & $14,172,704$ & $19,240,956$ & $12,645,033$ & $3,979,972$ & $8,665,061$ & $20,768,627$ & $10,192,732$ & $10,575,895$ & Total \\
\hline
\end{tabular}

Source : General Authority for Statistics (2019).

get old, we can expect changes in their sensory function, mobility, \& cognition. Such changes expectedly affect older people's interaction with their surrounding environment.

According to the General Authority for Statistics, the numbers of Saudis who are 65 years old \& over with mild to severe difficulty in sensory impairment, are shown in Table (3). The number of Saudis having difficulty in vision are $(34,910)$. It is worth mentioning that females account for $(12,913)$ (Table -4$)$.

People who are (65) years old \& more need special care when it comes to space design. More illumination is needed to see sharply; warm colors are preferred to cool colors, floor levels need to be specially treated, obstacles need to be avoided \& so on. 


\section{SENSORY IMPAIRMENT(Hearing)}

With aging comes another sensory impairment: hearing. Table (3) shows that there are $(7,641)$ Saudis who are $(65)$ years $\&$ over who suffer hearing difficulties ranging from mild to severe. The number may look less significant when compared to vision problems. However, architects have to consider an array of factors starting from space dimensions \& ratios, sources of noise, finishing materials, building insulation \& so on.[8]

Finally, other sensory impairments include age-related changes in touch \& temperature perception, in addition to olfactory impairment. Unfortunately, data related to these impairments are not collected by the General Authority for Statistics or other specialized scientific societies. Reduced sensitivity to high or low temperatures by human skin should be considered. Also, hazards of dangerous chemicals smelled by old people should be avoided.[9]

\section{MOBILITY}

Mobility problems facing the Saudi population are probably the greatest challenge which negatively impacts the welfare of the society. Saudi Arabia has the highest car accidents death rate among the (G20) nations. With a population of $(33,413,660)$ the number of fatalities was $(9,031)$ deaths per year. This represents $(28.8)$ deaths per $(100,000)$, compared to $(5.8)$ deaths in Canada, (12.4) in U.S.A., \& (22.6) in India. Car accidents resulting in deaths \& disabilities mean a loss of (3.5\% to $5.0 \%)$ percent of the GDP compared to only (1.5) percent in developed nations.[10]

In addition to deaths, the other accompanying result of car accidents is the number of bodily injuries resulting in real disabilities for passengers. According to Traffic Department Statistics, the number of injuries in 2018 was $(30,217)$, luckily enough dropping from a peak of $(38,120)$ in 2016. The drop was attributed to various efforts such as good medical care, rehabilitation programs, \& traffic disciplinary measures such as enforcing seat belt laws.[11]

\section{MOBILITY \& THE BUILT ENVIRONMENT}

Apparently, we have two groups of people who are candidates for primary help in the built environment due to their number \& their physical condition namely: elderly who are 65 years \& more, in addition to young people who are victims of car accidents.[12] Of course other types of accidents such as home related injuries can still be added to receive primary care in the built environment. According to an official survey in 2017, Saudi people who are 65 years of age \& over, faced difficulties in mobility, vision, \& hearing as follows: $(101,456-34,910-7,641)$ with a total of $(144,007)$. Their percentages are $(70.5 \%$ $-24.2 \%-5.3 \%)$ respectively. see (Table -3 ).

When we consider the number of Saudis having mobility problems (both young \& old), in addition to those having sensory problems (predominantly old), we have a serious problem that should be dealt with in planning \& designing the urban $\&$ the built environment. Our emphasis here will be on the built environment.

Table 3. Saudi Population (65 Years and over) Type of Difficulty and Their Severity.

\begin{tabular}{ccccc}
\hline & \multicolumn{4}{c}{ Difficulty Type } \\
\cline { 2 - 5 } $\begin{array}{c}\text { Their } \\
\text { severity }\end{array}$ & Total & $\begin{array}{c}\text { Difficult to walk } \\
\text { or climb stairs }\end{array}$ & Hearing & Seeing \\
\hline $\begin{array}{c}\text { Mild } \\
\text { Difficulty }\end{array}$ & 105932 & 75252 & 6641 & 24039 \\
$\begin{array}{c}\text { Severe } \\
\text { Difficulty }\end{array}$ & 38075 & 26204 & 1000 & 10871 \\
Total & 144007 & 101456 & 7641 & 34910 \\
\hline
\end{tabular}

Source : General Authority for Statistics (2017).

Table 4. Saudi Female Population (65 Years and over) Type of Difficulty and Their Severity.

\begin{tabular}{ccccc}
\hline \multirow{2}{*}{$\begin{array}{c}\text { Their } \\
\text { severity }\end{array}$} & Total & $\begin{array}{c}\text { Difficult to walk } \\
\text { or climb stairs }\end{array}$ & $\begin{array}{c}\text { Hearin } \\
\text { ny }\end{array}$ & Seeing \\
\hline $\begin{array}{c}\text { Mild } \\
\text { Severe/Ext } \\
\text { reme }\end{array}$ & 56052 & 45428 & 2464 & 8160 \\
Total & 22283 & 17451 & 79 & 4753 \\
\hline
\end{tabular}

Source : General Authority for Statistics (2017).

\section{GENERAL CONTEXT OF THE BUILT ENVI- RONMENT}

The building stockpile in Saudi Arabia is relatively new, with a quality that is continuously improving. This might reflect, among others, the per capita income of $(\$ 23,219)$. [13] The building industry is governed by various governmental agencies. They supervise \& direct 
the process of producing a building since its inception \& throughout later stages. In the case of public buildings, such agencies have an additional say in the operation of some buildings. Public participation in drafting laws \& regulations pertaining to the production of a building is minimum to non-existent. Governmental agencies include:

1. Municipalities

2. Civil Defense

3. Saudi Council of Engineers

4. Saudi Standards, Metrology, \& Quality Organization

5. Saudi Building Code

6. Architecture Schools

\section{Municipalities:}

Throughout their history, municipalities played a major role in shaping Saudi cities in addition to single buildings. Municipalities' Laws issued by a Royal Decree in 9/2/1977 defined the tasks to be undertaken by each municipality (17 tasks). When it comes to buildings, task No. 2 allowed the municipality to issue building permits based on a set of steps to be followed by the owner. [14]

In 17/11/1981 a Royal Decree stated all regulations \& stipulations to be implemented for the sake of making all public buildings accessible for the handicapped. A handicapped person may exhibit one or more of the following conditions:-

- Mental retardation

- Visual Impairment

- Hearing Impairment

- Mobility Limitation

The Decree document listed all the requirements to be implemented in the open space \& the built environment. They included: ramps, parking lots, pedestrian walkways for open spaces; \& handrails, signage, stairs, doors, windows, elevators, control switches, \& water fountains for closed buildings.[15]

\section{The General Directorate for Civil Defense (GDCD)}

It was founded in $22 / 7 / 1965$. Its mission is to act professionally to secure the safety of people \& properties \& protect them in times of peace, catastrophes, \& war. The closest activity to serving sensory impaired $\&$ handicapped people is limited to issuing licenses to buildings based on municipalities permits only. This means (GDCD) has no direct role to play in producing built environments suited for sensory impaired \& handicapped people.[16]

\section{Saudi Council of Engineers}

The Council aims at elevating the profession of engineering \& its members to new \& higher levels. Among its objectives comes the role of laying the basis \& specifications for professional practice, including: licensing exams, research, courses, conferences, technical advise... etc. [17].

Unfortunately, all criteria \& regulations published by (SCE) so far does not go beyond how to license engineering firms, offices, \& companies.

\section{Saudi Standards, Metrology, \& Quality Or- ganization}

SASO's mission is to elevate the standards $\&$ the quality of products \& services, to protect the consumer, \& to strengthen the competitiveness of the national economy.

SASO was established pursuant to the Royal Decree No. M/10 dated (17-4-1972). It is a competent authority entrusted with all matters related to standardization metrology, \& quality in Saudi Arabia.[18] In addition to its land mark services related to products \& services to consumers, SASO issued the first Saudi Building Code(SBC).[18]

\section{Saudi Building Code}

The code aims at setting the bare minimum requirements to achieve safety $\&$ public health through strength, stability, \& durability of buildings \& facilities, \& their means of access. In addition, providing a healthy environment, sufficient lighting \& ventilation, rationing of water, protection of lives \& properties from risks related to buildings.[19] The code is very comprehensive $\&$ wide ranging. It is planned to implement the code along five phases the first of which started a year ago (2018). The first two phases include governmental \& high rise buildings, in addition to educational buildings, commercial towers, \& industrial buildings. Residential buildings will be covered by the third phase (one year from today).

\section{Architecture Schools}

The first department of architecture was established in 1967 under the auspices of the College of Engineering, KSU. Today, there are ten (10) schools of architecture in Saudi Arabia 
with emphasis ranging from architecture to environmental design, \& engineering. In a recent doctoral study by Alhrabi, it was found that the aspect of mobility was covered in courses under different titles. They range from environmental control, to environmental behavior, professional practice, building specifications, ...etc.[20]

The analysis of the ten schools' curricula undertaken by the previous study lead us to conclude that the student graduates with a fairly good understanding of the needs exhibited by the sensory impaired \& the handicapped. Upon graduation, the student is not required to pass a licensing exam, which means he can start practicing without any prior field screening or experience. Adhering to any requirements regarding users with special needs is expected to be lacking, unless required by the client.

\section{CONCLUDING REMARKS}

The previous background analysis tells us that environmental design for people with special needs is still lagging. Apparently, agencies responsible for the enhancement of such environments are working in independent of each other. Even when the laws are there, the strategy for transforming laws into a reality is not there. Today this is true for public open space \& public buildings which are supposed to be the first to adopt Saudi Building Code.

Residential buildings are targeted to be covered by the Saudi Code in the third phase in 2020. This carries a paramount importance since such buildings will house the majority of young people affected by the tragic car accidents. A recent decree issued last September, 2019 by the Council of Ministers carries with it a glimpse of hope. It sets the terms for the implementation of the code in a detailed manner for the first time.

The Saudi Building Code is expected to furnish the minimum requirements for buildings, both public \& private. If \& when SBC is enforced comes after a long delay since the code was approved. Lack of mechanisms for enforcing SBC, in addition to shortages of human resources needed to supervise \& follow its enforcement, come as clear factors behind the delay.

Finally, it is vitally important to search for a coordinating body which brings all governmental agencies responsible for the creation of a built environment together. Every agency is headed by a public figure with ministerial power \& authority. Drawing on the experience of other competing governmental agencies, there seems to be a need for some kind of a (Higher Council) responsible for bringing those agencies together. Such a council should set the goals for quality built environments for all user, with the emphasis on those with special needs.

\section{References}

Plecher, H (2019). Saudi Arabia - Age Structure from 2007 to 2017. In Statista, $2-4$.

General Authority for Statistics (2019). Population in Kingdom by Gender, Age Group, \& Nationality (Saudi/Non-Saudi). Mid 2018 A.D.

Population of WORLD(2019). RoadTrafficinjuries.

General Authority for Statistics (2017). Population 65 Years \& over by sex.

Carr K., Weir P., Azar D., \& Azar N. (2013). Universal Design: A Step Toward Successful Aging. Journal of Aging Research. 1-8.

Dischinger Marta (2000). Designing for All Senses. Unpublished Ph.D. Thesis, Chalmers Univ. of Technology, Goteberg, Sweden.

Farage, M. A. et. Al (2012). Design Principles to Accommodate Older Adults, Global Journal of Health Science, 4(2): 2-25.

Ciorba A., Bianchini C., Pelucchi S., \& Pastor A (2012). The Impact of Hearing Loss on the Quality of Life of Elderly People. Clinical Interventions in Aging. 7, $159-163$.

Saunders G., Echt K. (2007). An Overview of Dual Sensory Impairment in Older Adults: Perspectives for Rehabilitation Trends in Hearing. $1-30$.

Makkah (2019). Saudi Has the highest Car Accidents Fatality among the (G 20). Local Newspaper, Feb. 17, 2019.

Alhayat (2019). 36 Thousand Fatalities \& Injuries in Car Accidents during the Year 1439H., Local Newspaper, August 26, 2019.

\begin{tabular}{cccc} 
World & Health & \multicolumn{2}{r}{ Organization } \\
(2018). & Road & Traffic & Injuries. \\
World Bank & (2019). & National & Accounts
\end{tabular}


Data, GDP per capita (current US \$).

Ministry of Municipal \& Rural Affairs

- MOMRA (2019). momra.gov.sa.

Riyadh Municipality (2019). Alriyadh.gov.sa

The General Directorate for Civil Defense (2019). Salamah.998.gov.sa

Saudi Council of Engineers (2019). Criteria for Engineering Professional Practice.

Saudi Standards, Metrology. \& Quality Organization (2019). saso.gov.sa

Saudi Building Code (2019). Sbc.gov.sa

Alhrabi. A. I. (2019). Developing the Ethics of Professional Practice in Construction: A Proposal Framework for Programs \& Plans of Architecture \& Planning Colleges in the Kingdom of Saudi Arabia. Unpublished Ph.D. Dissertation, King Saud University. 


\title{
مقالة خختصرة (غير محكمة)
}

\section{التصميــم لـذوي الإعاقـة الحسـية، كبــار الســن، والأشــخاص ذوي الإعاقــة

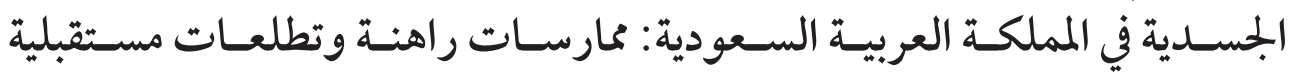

\author{
طارق بن محمد السليمان \\ استاذ \\ كلية العمارة والتخطيط، جامعة الملك سعود، المملكة العببية السعودية
}

Talsolman@ksu.edu.sa/tarikms@hotmail.com

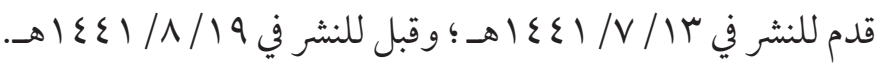

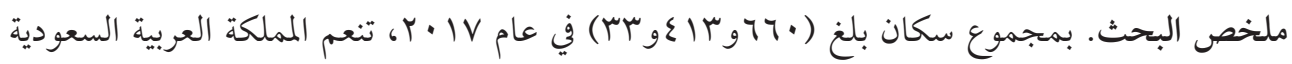

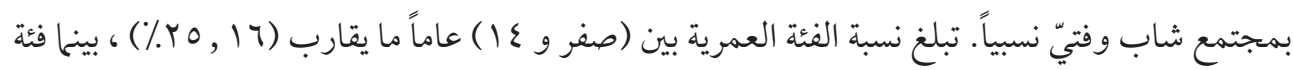

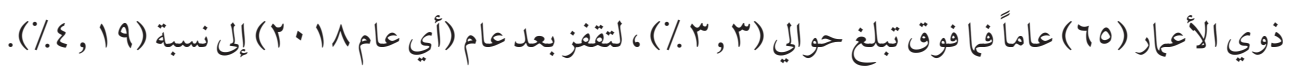
يتوقع أن تؤثر مظاهر الضعف الحسي (sensory impairment) ، إضافة إلى العجز الحركي (Mobility) على الطريقة

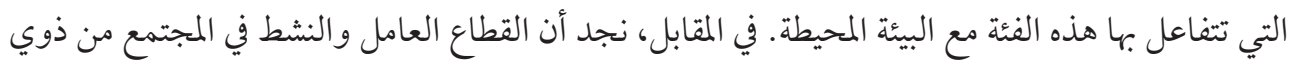

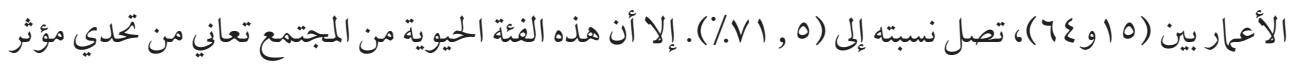

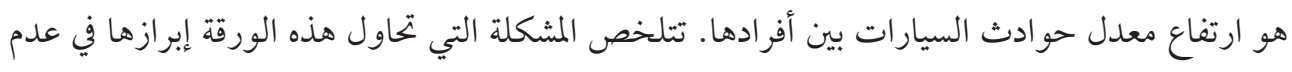

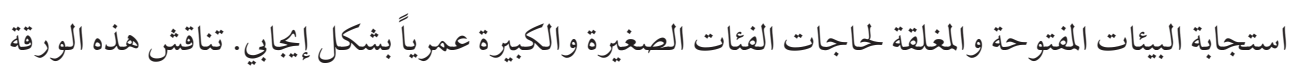

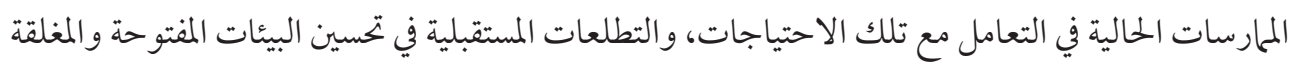
لكي تؤوي المجموعات السكانية ذات الاحتياجات الخاصة من كل الفئات العمرية. 